\title{
Recent Racial Incidents in Higher Education: A Preliminary Perspective
}

\author{
Walter C. Farrell, Jr., and Cloyzelle K. Jones
}

\begin{abstract}
The goal of this paper is to provide a contemporary perspective on the recent resurgence of racially motivated harassment and violence directed against minority students at predominantly white institutions of higher education. In achieving this goal, first an overview of minority student experiences on white campuses is given. Second, their experiences are linked to general perceptions of racism in contemporary society. Third, a delineation of the scope of racial-ethnic incidents on campuses of predominantly white institutions is made through a content analysis of a national and selected local and black-oriented newspapers. Finally, an assessment is made of the prospects for change. We argue that the recent upsurge in racism against minority students on white college and university campuses was implicitly encouraged by the previous national administration and by majority individuals in leadership roles. Finally, we argue that to combat these problems, university officials must begin to indicate in a direct way that racist actions will not be tolerated and that infractions will be dealt with severely.
\end{abstract}

In recent years there has been a resurgence of racial/ethnic conflict at predominantly white institutions of higher education. Incidents of harassment and violence at the University of Michigan, the University of Massachusetts, and other campuses have highlighted the continuing racial/ethnic divisions among majority and minority students (Wilkerson, 1988; Farrell, 1988a,b; Simpson, 1987; Wilkerson, 1988; Williams, 1987). These incidents have emerged during a period when the society, in general, has expressed concern about the declining enrollment of racial minorities-particularly blacks, Hispanics, and American Indians, and, to a lesser extent, Asians-in higher education. (For a detailed assessment of the issues surrounding the declining enrollment of racial minorities in predominantly white institutions of higher education, see the papers by Allen, Orfield, and Wang in this issue.)

Therefore, it is ironic that those minority students already enrolled in predominantly white institutions of higher education are experiencing increasing levels of racial-ethnic discrimination and hostility and have developed feelings

Walter C. Farrell, Jr., Department of Educational Policy and Community Studies, School of Education, University of Wisconsin-Milwaukee, Milwaukee, WI 53201. Cloyzelle K. Jones, School of Education, University of Michigan-Dearborn. 
of isolation on campus. This paper is a preliminary attempt to develop a perspective on this apparently worsening racial situation.

\section{OVERVIEW FROM THE LITERATURE}

\section{Minority Students on White Campuses}

Available research on minority students enrolled in predominantly white institutions of higher education has repeatedly affirmed that there is a poor fit between minority students' social, economic, and cultural status and that of the institutions (Allen, 1986; Fields, 1986, 1987; Fleming, 1984; Simpson, 1987). Although they evidence occupational aspirations similar to those of their white counterparts, minority students remain plagued by serious problems of institutional adjustment (Allen, 1986). They are more likely to be less academically prepared, to be of lower economic status, to be first generation college attenders, and to be disproportionately concentrated in two-year institutions (Thomas, 1981).

Moreover, the behaviors, lifestyles, and values of minority students are likely to be substantially different from those of whites. These factors, in turn, often have had a negative impact on their ability to successfully negotiate the university environment (Wilkerson, 1988); thus, their academic achievement suffers (Fields, 1986, 1987; Simpson, 1987). Universities, on the other hand, have made limited adjustments in their organizational and administrative structures and practices to accommodate the diverse and complex needs of their minority student populations, especially blacks, Hispanics, and American Indians. This institutional adjustment failure, in many respects, explains the substantial decline of these minority groups in higher education during the past decade.

Between 1976 and 1985, the high school graduation rate of black students rose from $65 \%$ to $75 \%$, while their college-going rate fell from $34 \%$ to $26 \%$. For Hispanics, high school graduation rates increased from $56 \%$ to $62 \%$, while their college-going rate fell from $36 \%$ to $26 \%$. In 1976 , black students constituted $9.4 \%$ of higher education enrollment, but that proportion had fallen to $8.8 \%$ by 1985 (Marks, 1985; Wilson and Melendez, 1986).

During the same period, Hispanics' share of enrollment went up from $3.5 \%$ to $4.3 \%$. However, it should be noted that the available pool of Hispanic students has increased even more substantially; thus, their college-going rate and their percentage of higher education enrollment is not keeping pace with their demographic trends (Change, 1988; Evangelauf, 1988; Fiske, 1987, 1988; Jaschik, 1987a,b). Among the minority student groups, Asian enrollment is growing most rapidly, and these students have encountered fewer problems of adjustment. American Indian students, however, fare least well overall.

Of all problems faced by minority students on predominantly white campuses, those of isolation, alienation, and lack of peer support appear to be the most serious. Minority students often have found it necessary to engage in 
voluntary segregation in order to survive the college experience (Allen, 1986; Bernstein, 1988; Jones, 1987a-d; Louis, 1987). The empirical and case study research suggests rather strongly that minority students are not adjusting successfully to predominantly white institutions under current conditions. Moreover, minority students find themselves at an additional disadvantage when they are forced to endure acts of racial discrimination and racism in addition to the continuing, "normal" problems of social, economic, cultural, and educational adjustment faced by all students whose backgrounds are not white and middle class.

\section{Racism in the Larger Society}

Many observers of the contemporary scene contend that racism against minorities is again on the upsurge and that its implicit encouragement by the national administration and by majority individuals in leadership roles has fueled this decline in racial tolerance (Carolinian, 1987b,c; Ferry, 1988; Heller, 1988; Holman, 1988; Iverem, 1987; Jackson, 1987; Jaroslovsky, 1984; Milwaukee Journal, 1988c; Purdum, 1987; The New Republic, 1987). These views are supported by a variety of studies which have pointed out that America is moving rapidly toward a separate and unequal society along the lines of race and class (Kotlowitz, 1988; Harris and Wilkins, 1988).

Even more disconcerting is the fact that senior White House staff members, during the Reagan Administration, allegedly made racial slurs concerning civil rights enforcement (Carolinian, 1987a). In addition, right wing extremists in the U.S. Department of Education and on the National Council for the Humanities were forced to resign because they had made disparaging remarks about racial minorities (Kusnet, 1987). What appears to be occurring is a societal capitulation to the promulgation of insensitive and racist attitudes and racist behaviors directed toward racial minorities (Carolinian, 1987c), a virtual epidemic of bigotry. Although there are those who decry this characterization of racism and racial insensitivity as forces in contemporary society (Marwell, 1988), it is clear that these societal characteristics are on the rise. (Milwaukee Community Journal, 1988).

The spread of racism and racial insensitivity may be due, in part, to societal uncertainty. Americans have expressed decreased levels of optimism about their future (Roberts, 1988). The emergence of the view that America is in a state of decline has generated a heightened level of insecurity and an intense focus on private concerns (Schmeisser, 1988). Consequently, minority students are having to pursue higher education in a climate of economic scarcity and uncertainty, which seems to be leading to greater racial intolerance (Jaschik, $1987 \mathrm{c}$ ). Although racial attitudes, as measured by survey trend data, indicate increased support for the principles of racial equality, these same surveys reveal substantially less support for those policies designed to insure equal treatment (University of Michigan, 1987; Johnson, 1989). 


\section{METHOD}

In order to develop a contemporary understanding of this problem, a general content analytical technique was employed to delineate the most significant current issues and factors surrounding racial/ethnic incidents on the campuses of predominantly white institutions of higher education (Babbie, 1983; Borg and Gall, 1979). Content analysis has been determined to be an effective tool for monitoring social change. During the past year, there has been an emergence of reportorial interest in racial/ethnic conflict on predominantly white university campuses; thus, the employment of this technique. The basic approach was to examine the patterns of focus in selected newspapers and other publications and to summarize emergent themes and trends.

For the purpose of this qualitative/descriptive analysis, a national newspaper, The New York Times, a local newspaper, The Milwaukee Journal, and selected black-oriented newspapers, The Carolinian, The Milwaukee Community Journal, and The Los Angeles Sentinel, were reviewed for the period, October 1, 1986 through December 15, 1988. In addition, related books, articles, and periodicals on these higher education issues (e.g., Chronicle of Higher Education and Black Issues in Higher Education) also were examined. The specific objectives of this investigation provided the focus of these assessments:

1. To provide an overview of minority students' status on white college campuses;

2. To examine the general issue of racism in contemporary society;

3. To determine the scope of racial/ethnic incidents on campuses of predominantly white institutions of higher education as reported in selected periodicals; and

4. To assess prospects for change.

Since this study was restricted to the aforementioned periodicals, it was not designed to capture all racial incidents that may have occurred on predominantly white university campuses during that time period. The intent here was to offer an initial assessment.

\section{CONTEMPORARY RACIAL INCIDENTS IN HIGHER EDUCATION}

\section{Content Analysis}

Recently reported racial incidents on predominantly white university campuses largely have been a result of conflicts between black and white students. Hispanic, Asian, and American Indian students, although experiencing increased levels of racial discrimination and harassment, have not emerged in this content analysis as being the primary victims of racism and racial insensitivity. However, it should be noted that the National Institute Against Prejudice and Violence "has documented racist incidents on 130 college campuses since the 1986-87 school year." Included in this documentation were 
"incidents of racial, religious, ethnic and homophobic violence and harassment" (Randolph, 1988, p. 128). Table 1 reveals that 37 racial incidents emerged from the content analysis during the time period under study. Even more interesting is the fact that four universities registered repeat incidents within the approximately two year time span.

By region, the northeastern sector of the nation evidenced the highest number of racial incidents, $14(38 \%)$, followed by the Midwest, $11(30 \%)$, the South, 8 $(22 \%)$, the West, $3(8 \%)$, and the Southwest, $1(3 \%)$. Every region of the country was represented (Table 2). Moreover, the years 1987 and 1988 approached parity in the number of incidents reported, $17(46 \%)$ and $20(54 \%)$, respectively.

The racial incidents were classified into seven types (Table 3):

1. Cross burnings-including burning of a shanty constructed by black students to protest apartheid in South Africa;

2. Racial discrimination-minority students' perceptions of unfair treatment and racial insensitivity;

3. Physical attacks - minority students being beaten by white students;

4. Racist literature-Distribution of racist fliers, racist graffitti, appearance of campus newspaper cartoons and articles portraying minorities in a derogatory light;

5. Racist remarks-public statements by white students, white faculty, or white university trustees demeaning minority students;

6. Racist behavior - performance of skits in blackface and Afro-wigs, mock slave auctions and mock hanging of a black, and general harassment of minority students by white students; and

7. Other-incidents of anti-Semitism and black students' protest for more minority faculty.

Of these forty incident types, acts of racial discrimination predominated at 10 (25\%), followed by racist remarks, $7(18 \%)$, racist behavior, $7(18 \%)$, and physical attacks, $4(13 \%)$. The remaining three incident types comprised less than $30 \%$ of the total, and all incidents were divided almost evenly across the two years in the aggregate and by category.

But in assessing the overall situation, an examination of the factors underlying these incidents revealed that they could be grouped under three basic headings: white insensitivity, environmental racism, and minority and majority student characteristics. Each will be discussed in turn.

\section{White Insensitivity}

A sizable proportion of white students, white staff, and white faculty at predominantly white institutions of higher education have experienced minimal contact with and exposure to minorities, particularly blacks, Hispanics, Asians, and American Indians. In addition, the general white population has not been encouraged or required to expand its social and cultural vistas in order to be 
TABLE 1.

Reported Racial Incidents at Selected U.S. Predominantly White Institutions of Higher Education, 1986-1988

\begin{tabular}{|c|c|c|c|}
\hline Institution & Year & $\begin{array}{l}\text { Description of } \\
\text { Racial Incident }\end{array}$ & $\begin{array}{l}\text { Recipient Racial } \\
\text { Minority Group }\end{array}$ \\
\hline Univ. of Massachusetts-Amherst & 1986 & Racial beating & Blacks \\
\hline Univ, of Michigan-Ann Arbor & 1987 & Racist fliers/racist jokes & Blacks \\
\hline Univ. of Alabama-Tuscaloosa & 1987 & Cross burning & Blacks \\
\hline The Citadel, Charleston, S.C. & 1987 & Cross burning & Blacks \\
\hline Purdue Univ., West Lafayette, Ind. & 1987 & Cross burning & Blacks \\
\hline Univ. of Texas-Austin & 987 & Verbal threats & Blacks/Hispanics \\
\hline Columbia Univ., New York City & 1987 & Physical attacks & Blacks \\
\hline Northern Illinois Univ., Dekalb & 1987 & Racist remarks/fliers & Blacks \\
\hline Univ. of Wisconsin-Madison & 1987 & Black-face fraternity party & Blacks \\
\hline Univ. of Virginia-Charlottesville & 1987 & Racial discrimination & Blacks \\
\hline Farleigh Dickinson Univ., N.J. & 1987 & Racial brawl & Blacks \\
\hline MTT, Cambridge, Mass. & 1987 & $\begin{array}{l}\text { Racial isolation/ } \\
\text { condescension }\end{array}$ & $\begin{array}{l}\text { Blacks/Asians } \\
\text { Hispanics }\end{array}$ \\
\hline Tulane Univ., New Orleans, La. & 1987 & Black-face fraternity party & Blacks \\
\hline $\begin{array}{l}\text { Dartmouth College, } \\
\text { Hanover, N.H. }\end{array}$ & 1987 & $\begin{array}{l}\text { Racial slurs/verbal } \\
\text { assaults }\end{array}$ & Blacks \\
\hline Univ. of Pittsburgh & 1987 & Racial insensitivity & Blacks \\
\hline Univ. of Pennsylvania & 1987 & $\begin{array}{l}\text { Racial degradation/ } \\
\text { insensitivity }\end{array}$ & Blacks \\
\hline Univ. of Wisconsin-Milwaukee & 1988 & Racist fliers/remarks & Blacks \\
\hline $\begin{array}{l}\text { Marquette Univ., Milwaukee } \\
\text { Hampshire College, }\end{array}$ & 1988 & Physical beating & Blacks \\
\hline Amherst, Mass. & 1988 & Racist treatment & Blacks \\
\hline Harvard Univ. Law School & 1988 & $\begin{array}{l}\text { Black students demand } \\
\text { more minority faculty }\end{array}$ & Blacks \\
\hline Denison Univ., Granville, Ohio & 1988 & Racist slurs & Blacks \\
\hline Univ. of Kentucky, Lexington & 1988 & Racist remarks by trustee & Blacks \\
\hline Penn State Univ., Univ. Park & 1988 & Racial discrimination & Blacks \\
\hline $\begin{array}{l}\text { Univ. of Wisconsin, } \\
\text { Eau Claire }\end{array}$ & 1988 & $\begin{array}{l}\text { Racist cartoon in } \\
\text { student newspaper }\end{array}$ & Blacks \\
\hline Univ. of California-Berkeley & 1988 & Racial harassment & Blacks \\
\hline Univ, of California-Los Angeles & 1988 & Racial discrimination & Blacks/Hispanics \\
\hline Univ. of Mississippi & 1988 & $\begin{array}{l}\text { Racist behavior/ } \\
\text { racist party }\end{array}$ & Blacks \\
\hline Stanford Univ. & 1988 & $\begin{array}{l}\text { Racism/cultural insensi- } \\
\text { tivity/racial harassment }\end{array}$ & Blacks \\
\hline Yale Univ. & 1988 & $\begin{array}{l}\text { Burning of shanty } \\
\text { protesting apartheid }\end{array}$ & Blacks \\
\hline Univ, of Arizona & 1988 & $\begin{array}{l}\text { Harassment of } \\
\text { Jewish faculty }\end{array}$ & Jews \\
\hline Syracuse University, Syracuse, N.Y. & 1988 & Anti-Semitism & Jews \\
\hline $\begin{array}{l}\text { Indiana Univ., Bloomington } \\
\text { Williams College, }\end{array}$ & 1988 & Racial beating & Blacks \\
\hline Williamstown, Mass. & 1988 & Affirmative action protest & Blacks \\
\hline Centre College, Kentucky & 1988 & Mock racial hanging & Blacks \\
\hline${ }^{b}$ Univ. of Wisconsin, Madison & 1988 & Slave auction/blackface skit & Blacks \\
\hline${ }^{b}$ Northern Illinois Univ., DeKalb & 1988 & Blackface skit & Blacks \\
\hline${ }^{b}$ Dartmouth College & 1988 & $\begin{array}{l}\text { Racially/ethnically biased } \\
\text { and sexist newspaper articles }\end{array}$ & Blacks/Women/Jews \\
\hline${ }^{b}$ Univ. of Massachusetts, Amherst & 1988 & Racial discrimination & $\begin{array}{l}\text { Blacks/Hispanics/ } \\
\text { American Indians }\end{array}$ \\
\hline
\end{tabular}

${ }^{a}$ Incidents perpetrated by majority students against minority students.

${ }^{b}$ Reported racial incidents in 1987 and 1988. 
TABLE 2.

Racial Incidents by Region, 1987-1988

\begin{tabular}{ccccccc}
\hline Year & NE & MW & S & W & SW & Total \\
\hline 1987 & $8^{a}$ & 4 & 5 & 0 & 0 & 17 \\
& $22 \%^{b}$ & $11 \%$ & $14 \%$ & $0 \%$ & $0 \%$ & $46 \%$ \\
& $57 \%^{c}$ & $36 \%$ & $63 \%$ & $0 \%$ & 0 & $46 \%$ \\
1988 & 6 & 7 & 3 & 3 & 1 & 20 \\
& $16 \%$ & $19 \%$ & $8 \%$ & $81 \%$ & $3 \%$ & $54 \%$ \\
& $43 \%$ & $64 \%$ & $37 \%$ & $100 \%$ & $100 \%$ & $54 \%$ \\
& $4^{d}$ & 11 & 8 & 3 & 1 & 37 \\
& $38 \%$ & $30 \%$ & $22 \%$ & $8 \%$ & $3 \%$ & $100 \%$ \\
& $100 \%$ & $100 \%$ & $100 \%$ & $100 \%$ & $100 \%$ & $100 \%$ \\
\hline
\end{tabular}

${ }^{a}$ Includes one incident from late 1986.

${ }^{b}$ Percent of Total.

${ }^{c}$ Percent of Region.

${ }^{d}$ Percentages do not equal $100 \%$ due to rounding.

Regions: $\mathrm{NE}=$ Northeast; $\mathrm{MW}=$ Midwest; $\mathrm{S}=$ South; $\mathrm{W}=\mathrm{West} ; \mathrm{SW}=$ Southwest.

sensitive to the social, economic, and cultural backgrounds of minority students. As presented above, there have been numerous examples of the indiscriminant use of racial slurs, racial jokes, and racist paraphanelia directed toward minority groups by white students.

But perhaps more insidious are the quiet acts of racial discrimination whereby minority students come to feel that they are not welcome to participate in the

TABLE 3.

Racial Incidents by Type, 1987-1988

\begin{tabular}{ccccccccc}
\hline & $\begin{array}{c}\text { Cross } \\
\text { Burnings } \\
\text { Year }\end{array}$ & $\begin{array}{c}\text { Racial } \\
\text { Discrimi- } \\
\text { nation } \\
\text { (RD) }\end{array}$ & $\begin{array}{c}\text { Physical } \\
\text { Attacks } \\
\text { (PA) }\end{array}$ & $\begin{array}{c}\text { Racist } \\
\text { Literature } \\
(\text { RL) }\end{array}$ & $\begin{array}{c}\text { Racist } \\
\text { Remarks } \\
\text { (RR) }\end{array}$ & $\begin{array}{c}\text { Racist } \\
\text { Behavior } \\
\text { (RB) }\end{array}$ & Other & Total \\
\hline 1987 & 3 & 5 & 3 & 2 & 4 & 2 & 0 & 19 \\
& $7 \%^{b}$ & $13 \%$ & $7 \%$ & $5 \%$ & $10 \%$ & $5 \%$ & $0 \%$ & $46 \%$ \\
& $75 \%^{c}$ & $50 \%$ & $60 \%$ & $50 \%$ & $57 \%$ & $29 \%$ & $0 \%$ & $54 \%$ \\
1988 & 1 & 5 & 2 & 2 & 3 & 5 & 3 & 21 \\
& $3 \%$ & $13 \%$ & $5 \%$ & $5 \%$ & $4 \%$ & $13 \%$ & $7 \%$ & $54 \%$ \\
& $25 \%$ & $50 \%$ & $40 \%$ & $50 \%$ & $43 \%$ & $71 \%$ & $100 \%$ & $46 \%$ \\
& 4 & 10 & 5 & 4 & 7 & 7 & 3 & 40 \\
& $10 \%$ & $25 \%$ & $13 \%$ & $10 \%$ & $18 \%$ & $18 \%$ & $74 \%$ & $100 \%$ \\
& $100 \%$ & $100 \%$ & $100 \%$ & $100 \%$ & $100 \%$ & $100 \%$ & $100 \%$ & $100 \%$ \\
\hline
\end{tabular}

${ }^{a}$ Incident types total more than 37 since one or more types comprised the single campus report in some instances.

${ }^{b}$ Percent of total racial incidents.

${ }^{c}$ Percent of racial incident types.

${ }^{d}$ Percentages do not equal $100 \%$ due to rounding. 
total life of the university irrespective of their intellectual ability and previous academic success (Louis, 1987; Simpson, 1987; Wilkerson, 1988). These subtle, interracial exchanges, often involving white faculty members as well as white students, result in a self-fulling prophecy. They are rarely reported in the media or acknowledged by university officials. Moreover, "many of these students are away from home for the first time and have never encountered such behavior from their peers or teachers" (Milwaukee Community Journal, 1987).

Finally, minority students are negotiating a virtual gauntlet of racially insensitive behaviors and enduring reigns of racist terror on the more racially volatile campuses, where there are recurrences of racial incidents of such a magnitude that they have received national medial attention (New York Times, 1988i).

In response to these chronic acts of racism and racial insensitivity, university administrators have most frequently chosen to initiate programs to increase minority student enrollment rather than to confront racist behavior directly by issuing strong sanctions. They appear to operate under the implicit assumption that the mere increase in minority student enrollment will result in a decrease in racially discriminatory behavior on the university campus (Johnson, 1987; Jones, 1987a-d, 1988a-d). Nonetheless, as a result of these repeated incidents, several higher education administrators have initiated required ethnic orientation courses, conducted reviews of policies governing student behavior, and have assessed the racial climate of their campus environments (Camper, 1988; Shaw, 1988; Yardley, 1988).

\section{Environmental Racism}

The larger university community often supports racial discrimination within the university. For instance, restaurants, bars, and other social outlets for students in close proximity to university campuses have frequently permitted, if not encouraged, racial intolerance by their actions. For example, it has been reported that:

1. Campus bars may discourage minority student patronage by structuring the bar environment to deter minority students (e.g., not playing minorityoriented music, not hiring minority students as workers, etc.).

2. Restaurants, bars, and movie theaters may permit racial slurs and jokes to be made on premises.

3. Restaurants may be slow to serve minority students and/or treat them in a hostile manner.

4. Local police officers often closely monitor the activities of minority students (particularly minority males) when they enter the communities surrounding predominantly white institutions, especially when these communities are overwhelmingly white.

5. Local public officials, like their university counterparts, rarely publicly denounce the expressions of racism in their community. 
These businesses and civic leaders in the close-by, but off-campus environment, appear to be taking their cues from the majority students with respect to the negative racial behaviors that they will accommodate. Furthermore, university administrators seldom monitor campus-area establishments to ascertain the quality of treatment received by their students, in general, and their minority students in particular (Friedrich, 1987; Johnson, 1987; Jones, 1987a-d, 1988a-d; Stanford, 1987).

\section{Minority and Majority Student Characteristics}

Today's minority college students, largely from low-income, working-class communities, represent the most assertive minority generation ever to enter higher education. They are by-products of the cultural and social transformations of the $1960 \mathrm{~s}$ and early $1970 \mathrm{~s}$, where for the first time, large numbers of them questioned, and frequently rejected, the value system governing the society. It was at this juncture that minorities began to establish new frames of cultural and social reference (Carolinian, 1988b). Sowell (1989) has concluded that this cultural view, coupled with their lack of academic preparedness for many of the predominantly white institutions in which they are enrolled, has led to a white student backlash which is reflected in the upsurge in campus racial incidents.

But it must be recognized that the wider access to higher education for minority students also has been accompanied by expanded higher education opportunities for poor whites via loans, campus jobs, and flexible admission standards. Thus more working-class, poor white students are also entering higher education. This latter group is one of the more racially intolerant groups in society. Middle class white students, particularly the upper middle class group (in values if not in income), who dominated college campuses in social influence, if not in number, in earlier periods (the 1960s and into the 1970s) included a subgroup, who out of utopian attitudes welcomed minority students on campus and who tended to form support groups for them against harassment. These support groups have disappeared as the students, like their parents and out of school peers, are focusing more intensely on private concerns. Meanwhile "all that remains unresolved between blacks and whites, all the old wounds and shames . . . present themselves for attention-and present our youth with pressures they cannot always handle." (Steale, 1989, 49).

Therefore, the campus racial tensions of today are driven, in part, by the substantially changed social and cultural characteristics of competing racial and ethnic student groups. The desegregation of higher education has not generally resulted in minority and majority students interacting collegially in an environment of mutual respect. The expressed attitudes and behaviors of these students reflect a socialization process learned at home. And while increasing numbers of majority students are engaging in virulent acts of racism, most are evidencing subtle and sophisticated acts of discrimination which keep many predominantly white campuses at the racial boiling point (Carolinian, 1988b). 
Examples of chronic racist incidents, not reported in our content analysis, are at the core of campus racial unrest (Wilkerson, 1988). Contemporary minority students, who are articulate and assertive and who are operating from new phenomenological and existential constructs, are refusing to accommodate social, physical, and cultural assaults on their humanity. Accordingly, predominantly white university campuses which are likely to experience racial conflict evidence the risk factors shown in Table 4 . These factors, all together or in substantial combination, have undergirded the reported racial incidents in this analysis. The extent to which they remained largely unaddressed after the occurrence of the initial incident also was indicative of campuses with repeated incidents. Although this index of risk factors was developed from a detailed assessment of only 37 racial incidents with high media visibility, they are consistent with those factors which led to the 130-160 campus racial incidents documented by the National Institute Against Prejudice and Violence during the past three years (Randolph, 1988; Steele, 1989). Given this reality, the question is not whether there will be other incidents, but rather where will they occur next and what will we do about them?

\section{Summary}

A preliminary content analysis of selected periodicals revealed quite clearly that the problems being faced by minority students on white college campuses are of concern to the larger society. The reporting and interpretation of racist

\section{TABLE 4.}

Risk Factors for Racial Incidents on Predominantly White University Campuses ${ }^{a}$

1. Large enrollments in general terms or in residential enrollment as a percent of the student population.

2. Campuses located in isolated college towns.

3. Unclear rules for student conduct and weak and/or nonexistent sanctions for racist/ sexist behavior.

4. Substantial numbers of low-income, working-class majority students whose previous residence has been in majority or nearly majority cities and towns.

5. Weak leadership at the central administrative level of the university with respect to a consistent and clear commitment to racial and gender equity.

6. Failure by the university administration to act swiftly and decisively once a racial incident has occurred.

7. Ineffective minority student support programs.

8. Small numbers of minority faculty and staff at the institution.

9. Lack of university programming/initiatives to bridge the cultural and social gap between majority and minority students.

\footnotetext{
${ }^{a}$ Risk factors are not ranked.
} 
incidents by national and regional newspapers demonstrate the depth of this concern. Nonetheless, the mere acknowledgment of the gravity of the situation does not offer sanguine prospects for change. What also has been revealed is that in too few instances have chief administrators in higher education-save a few-responded with creative, aggressive, and programmatic leadership which might lead to meaningful and substantive change (Gold, 1988h; Kingson, 1988; Shaw, 1988). Many have taken the naive posture that the due process protections of the Constitution do not permit them to make even general public statements against racism and racial insensitivity on their campuses prior to a formal ruling on the specific incident. This failure of administrative leadership unwittingly sends the message to all students that the university is tolerant of racist behaviors (Farrell, 1988c).

In most situations the responses suggest a reiteration of strategies of the past which were not successful then and are not likely to be successful now (Sowell, 1989). Although many would suggest that universities have been working at their problems of racial discrimination and declining minority enrollment, it is urgent that more immediate progress be made.

\section{PROSPECTS FOR CHANGE}

If universities are truly concerned about the presence of minorities within their student bodies, university officials must begin to indicate in a direct way that "racist actions" will not be tolerated and that infractions will be dealt with severely (Milwaukee Community Journal, 1988; Milwaukee Courier, 1988; Short, 1987). And if minority students are not given this explicit signal of commitment, they will be neither attracted to nor retained in these institutions. A concomitant strategy to counter such attitudes would be for colleges and universities to integrate their faculties and staffs so as to reflect the diversity of the larger society (Gold, 1988g; Massey, 1987). Although it is imperative that the environment on campuses of higher education be conducive to learning, the larger society must implement safeguards that impose sanctions against those who act to harass others because of their racial/ethnic differences.

"From random insults on the street to graffiti in dorms to fistfights on fraternity row, minorities are increasingly viewing a major part of their education as learning how to cope with racism" (Connel, 1988, p. 13). As Robert Atwell, president of the American Council on Education, has stated so eloquently, "We have hit the wall on minority participation and are loath to face the tough road ahead. Our own inner fatigue has been accentuated by an administration that has not seen equity issues as important" (quoted in Connell, loc. cit.).

Nonetheless, although there has been inaction and ineptitude among higher education administrators and public officials in their response to the rising tide of campus racism, there have been instances of aggressive leadership. The president of Dartmouth issued a formal statement in which he castigated a conservative student newspaper for its insensitive and inflammatory comments 
on blacks, women, and homosexuals (Gold, 1988h). Elsewhere, the chancellor of the University of Massachusetts diffused a racially volatile situation by assisting black students in turning their demands into an agenda that the university could support in facilitating racial harmony (Kingson, 1988).

In Wisconsin, the lieutenant governor used the occasion of his May, 1988 commencement address at the University of Wisconsin-Madison to remind the graduates of the ugliness and hurt of racist behavior on their campus. He challenged them to accept the responsibility for creating a racially just society (Milwaukee Journal, 1988d). The president of the University of Wisconsin system also issued a design for diversity in which he is holding the 15 constituent universities accountable, via specific evaluation criteria, for improving their overall campus environments for minority and majority students alike. In promulgating this edict, he withstood considerable opposition statewide (Shaw, 1988). Even more recently, the president of Georgia Southern College suspended a majority tenured faculty member for making a racially inflammatory remark to a black student in his class. In taking this action, the president rejected a milder faculty sanction (Black Issues in Higher Education, 1988).

These instances of leadership are infrequent and unheralded, but they offer evidence that the resolution of campus racial conflict is indeed possible. It is imperative that we not continue to allow the casual nature of racism to envelop the progress that we have made during the past quarter century.

\section{NOTES}

1. The following references served as sources for the ensuing discussion, in addition to references cited in the text: Associated Press (1988); Chronicle of Higher Education (1987, 1988); Connell (1988); Farrell (1987, 1988b); Farrell and Pollard (1987); Friederich (1987); Gibson and Mitchell (1988); Gibney (1988); Gold (1988a f,h; Jet (1987, 1988a-c); Milwaukee Journal (1987a-c, 1988a-e); Michigan Alumnus (1987); The New York Times (1988a-i); Olive (1988); Stevens (1988a-b); Tobin (1987); Wilson (1986); Change (1988); Yardley (1988).

\section{REFERENCES}

Allen, Walter R. (1986). Gender and campus race differences in black student academic performance, racial attitudes and college satisfaction. Atlanta, GA: Southern Educational Foundation.

Associated Press (1988, April 8). Chandler says he's sorry for comment. The Milwaukee Sentinel, p. 4 (part 2).

Babbie, Earl (1983). The Practice of Social Research (3rd ed.). Belmont, CA: Wadsworth.

Bernstein, Richard (1988, July 10). Asian newcomers hurt by precursors' success. The New York Times, p. 12.

Bernstein, Richard (1988, May 26). Black and white on campus: Learning tolerance, not love, and separately. The New York Times, p. 8.

Black Issues in Higher Education (1988). Judge refuses to lift suspension of Georgia professor for racist remark. 5(14): 3 . 
Borg, Walter R., and Gall, Meredith D. (1979). Educational Research. An Introduction. New York: Longman.

Camper, Diane (1988, June 10). When racism goes to college. The New York Times, p. 24.

The Carolinian (1987a, Oct. 2). Racist jokes, slurs heard in White House, pp. 1, 2.

The Carolinian (1987b, Nov. 19). King wants students to battle injustices, p. 2.

The Carolinian (1987c, Dec. 12). Woman professor quits due to discrimination, p. 9.

The Carolinian (1988a, Jan, 4). USA racism alive and well says Thurgood Marshall, p. 5.

The Carolinian (1988b, May 2). Student unrest is simply symbolic, p. 4.

Change (1988, May/June). Hispanics higher education's missing people, pp. 12-65.

Chronicle of Higher Education (1987, October 28). Racial brawl involves 40 at Farleigh Dickenson University, p. A2.

Chronicle of Higher Education (1988, April 20). Racial incidents of 4 universities spark protest, pp. A39-40.

Collison, Michelle (1988, May 25). Neglect of minorities seen jeopardizing future prosperity. Chronicle of Higher Education, pp. A1, A20.

Connell, Christopher (1988, May). Often college means a course in racism. The Carolinian, p. 13.

Evangelauf, Jean (1988, March 9). Minorities' share of college enroliments edges up, as number of Asian and Hispanic students soars. Chronicle of Higher Education, pp. A33, A35.

Farrell, Charles (1988a, February 17). Rising concern over campus racial bias marked at Northern Illinois conference. Chronicle of Higher Education, pp. A35-A36.

Farrell, Charles (1988b, February 24). Students protesting racial bias at University of Massachusetts end occupation of campus building after 5 days. Chronicle of Higher Education, pp. A41-A42.

Farrell, Perry A. (1987, November 10). Racial problems concern Morton. The Milwaukee Journal, pp. $1 \mathrm{C}$ and $2 \mathrm{C}$.

Farrell, Walter C. (1988c, November 28). Letter to Senator Gary R. George, co-chairman of the joint finance cormmittee, Wisconsin State Legislature regarding racist incidents at the University of Wisconsin-Madison.

Farrell, Walter C., Jr., and Pollard, Diane S. (1987). An examination of factors associated with minority sudent decisions to pursue higher education: A case study of three Wisconsin school districts. Milwaukee, WI: University of Wisconsin-Milwaukee Graduate School.

Ferry, W. H. (1988, February 14). Racism in the FBI is a Hoover legacy. (letter to the editor) The New York Times, p. 20.

Fields, Cheryl M. (1986, September 16). Closing the education gap for Hispanics: State aims to forestall a divided society. Chronicle of Higher Education, pp. A1, A33, A37-A38.

Fields, Cheryl M. (1987, September 30). Colleges in California seek new ways to expand pool of Hispanic students prepared for higher education. Chronicle of Higher Education, pp. A31, A33-A34.

Fiske, Edward B. (1987, November 18). Colleges open new minority drives. The New York Times, p. 12.

Fiske, Edward B. (1988, March 3). Colleges are seeking lag in their Hispanic enrollment. The New York Times, pp. 1, 16.

Fleming, Jacqueline (1984). Blacks in College. San Francisco: Jossey-Bass.

Foderaro, Lisa W. (1988, February 28). Attack on black women stuns mostly white New Jersey Town. The New York Times, p. 18.

Foxman, Abraham H. (1988, June 17). Campus bigotry incidents show an increase. The New York Times, p. 26.

Friederich, Charles E. (1987, November 11). Blacks urge stand against racism. The Milwaukee Journal, pp. 1B, 7B.

Gibney, James S. (1988, April 11). The Berkeley squeeze. The New Republic, pp. 15-17.

Gibson, Sharon, and Mitchell, Thomas (1988, March 9). UWM, Marquette respond differently to racial incidents. The Milwaukee Community Journal, pp. 1, 11.

Gold, Alan R. (1988a, February 18). Black demonstrators refuse to meet university's chief. The New York Times, p. 8. 
Gold, Alan R. (1988b, February 18). Students end takeover at University of Massachusetts. The New York Times, p. 8.

Gold Alan R. (1988c, February 16). Cordiality and racial anger mix in Massachusetts University Protest. The New York Times, p. A10.

Gold, Alan R. (1988d, February 21). Campus racial tensions-and violence-appear on rise. The New York Times, p. 6E.

Gold, Alan R. (1988e, March 2). Clash between teacher and student paper fuels racial tension at Dartmouth. The New York Times, p. 16.

Gold, Alan R. (1988f, March 5). Dartmouth holds meeting to end racism on campus. The New York Times, p. 7.

Gold, Alan R. (1988g, May 11). Harvard Law School blacks hold sit-in on faculty hiring. The New York Times, p. 13.

Gold, Alan R. (1988h, May 11). "Outsider" who stirred emotions at Dartmouth. The New York Times, p. 23.

Harris, Fred R., and Wilkins, Roger W., eds. (1988). Quiet Riots. New York: Pantheon.

Heller, Scott (1988, January 20). Bloom's best seller called racist and elitist by former SUNY chief. Chronicle of Higher Education, pp. A1, A12.

Holman, M. Carl (1988, May 19). Black students under attack in particularly vicious race war. The Carolinian, p. 1.

Iverem, Esther (1987, December 14). Three racial incidents unsettle Hudson Valley. The New York Times, p. 13.

Jackson, Jesse (1987, January 19). Atonement for racist episodes isn't enough. The New York Times, p. 17.

Jaroslovsky, Rich (1984, September 28). Racial purists use Reagan plug. The Wall Street Journal, p. 46.

Jaschik, Scott (1987a, September 7). College outlook grim for blacks 25 years after barriers fell. Chronicle of Higher Education, pp. A88-A91.

Jaschik, Scott (1987b, November 25). Major changes seen needed for colleges to attract minorities. Chronicle of Higher Education, pp. A1, A31-A32.

Jaschik, Scott (1987c, November 18). Chief of Wisconsin University system ignites passions with proposal to waive tuition for minority students. Chronicle of Higher Education, pp. A24-A26.

Jet (1987, November 9). Blacks protest at University of Virginia on race bias, p. 6.

Jet (1988a, May 16). Students end takeover at Williams College, p. 22.

Jet (1988b, May 6), Racial attack stirs ire in blacks at Indiana University, p. 1.

Jet (1988c, Dec. 13). Ky. frat apologizes for mock lynching on campus, p. 23.

Johnson, Julie (1989, January 12). Poll finds blacks and whites worlds apart on race issues. The New York Times, p. 7.

Johnson, Raymond E. (1987, May 6). Blacks describe a racist campus. The Milwaukee Journal, p. 1.

Jones, Richard P. (1987a, November 9). Two stories of pain, prejudice: Scom stuns blacks at UW. The Milwaukee Journal, pp. 1A, 6A.

Jones, Richard P. (1987b, November 1). Racist incidents hurt $\mathrm{UW}$ recruiting efforts. The Milwaukee Journal, pp. 1A, $20 \mathrm{~A}$.

Jones, Richard P. (1987c, October 31). UW fraternity suspended again over new claims of racism. The Milwaukee Journal, pp. 1A-2A.

Jones, Richard P. (1987d, November 4). UW rally to challenge racism on Madison campus. The Milwaukee Journal, pp. 1B, 7B.

Jones, Richard P. (1988a, April 21). Stories differ in attack on UW student. The Milwaukee Joumal, p, $14 \mathrm{~A}$.

Jones, Richard P. (1988b, May 15). Lesson in racism. The Milwaukee Journal, pp. 1, 8.

Jones, Richard P. (1988c, May 16). No easy cure: UW blacks favor minority plan but are cool to campus. The Milwaukee Journal, pp. 1A, 8A.

Jones, Richard P. (1988d. May 3). Racial slurs targeted by UW faculty. The Milwaukee Journal, pp. 1A, 6A. 
Jones, Richard P. (1988e, Oct. 25). Eight protesting racial skits are arrested. The Milwaukee Journal, pp. 1A, 8A.

Kingson, Jennifer (1988, February 24). Deflecting student protests with open heart and mind. The New York Times, p. 14.

Kotlowitz, Alex (1988, February 26). Blacks' hopes, raised by '68 Kerner Report, are mainly unfulfilled. The Wall Street Journal, pp. 1, 8.

Kusnet, David (1987, November 2). Extremists in high places are often forced to resign office. The Carolinian, pp. 1-2.

Los Angeles Sentinel (1988, June 2). Vigil by students in masks angers blacks, pp. A1-A23.

Louis, Errol T. (1987, August). Racism on campus. Essence, pp. 53, 120, 122.

Mark, J. L. (1985). The enrollment of blacks in higher education: Can declines be prevented? Atlanta, GA: Southern Regional Education Board.

Marwell, Gerrald (1988, May 27). What epidemic of campus bigotry. The New York Times, p. 22.

Massey, Walter E. (1987, July 15). If we want racially tolerant students we must have more minority professors. Chronicle of Higher Education, p. 76.

Michigan Alumnus. (1987, May/June). Racism on campus.

The Milwaukee Community Journal (1987, November 4). UW system must put foot down on campus racism, p. 2.

The Milwaukee Community Journal (1988, November 16). Skinheads spearhead wave of racial violence, pp. 1 and 5.

The Milwaukee Courier (1988, March 12). Area students protest racism, pp. 1, 3.

The Milwaukee Journal (1987a, November 5). UW officials, regents must give higher priority to combating racism, p. 16A.

The Milwaukee Journal (1987b, November 7). Seventy-five rally at UW fraternity, p. 5A.

The Milwaukee Journal (1987c, November 9). Shaw's tuition proposal called divisive, p. 6A.

The Milwaukee Journal (1988a, April 16). Racial cartoon was wrong, students on newspaper say, p. $7 \mathrm{~A}$.

The Milwaukee Journal (1988b, April 18). Campus racism protest coincides with release of UW minority report, p. 5B.

The Milwaukee Journal (1988c, April 24). Bennett blast at Stanford shows narrow aim, p. 6J.

The Milwaukee Journal (1988d, May 22). McCallum gives grads real-world warning, p. $6 \mathrm{~J}$.

The New Republic (1987, Feb. 9). Rethinking race, pp. 7-10.

The New York Times (1988a, February 17). Accord is seen in student protest on racism at University of Massachusetts, p. 19.

The New York Times (1988b, March 3). Minority students end protest at Hampshire, p. 13.

The New York Times (1988c, April 7). Students in Berkeley complain of racism and seize building, p. 11.

The New York Times (1988d, April 19). Penn State will grant amnesty against 89 in a students' protest, p. 12.

The New York Times (1988e, April 20). Penn State worries arrests may hurt minority efforts, p. 25.

The New York Times (1988f, May 29). U.C.L.A. protesters disrupt voting for student president, p. 22.

The New York Times (1988g, June 7). Racial motive denied in shanty fire at Yale, p. 11.

The New York Times (1988h, June 19). When racism goes to college, p. 24.

The New York Times (1988i, Oct. 28). Inquiry on fraternity slave auction, p. 13.

Olive, Ralph D. (1988, February 12). MU officials looking into racial scuffle. The Milwaukee Journal, p. 1 B.

Park, Roderick B. (1988, April 20). No racial majority at Berkeley y '89. The New York Times, p. 26.

Purdum, Todd S. (1987, November 1). Crimes of prejudice a matter of motive. The New York Times, p. 6.

Randolph, Laura B. (1988). Black students battle racism on college campuses. Ebony, Dec.: $126-130$. 
Roberts, Steven (1988, February 21). Poll finds less optimism in U.S. on future, a first under Reagan. The New York Times, pp. 1, 18.

Schmeisser, Peter (1988, April 17). Is America in decline? The New York Times, pp. 24-25, 66-68, 96.

Shaw, Kenneth A. (1988). A Design for Diversity. Madison, WI: University of Wisconsin System.

Short, Carolyn R. (1987, November 15). Colleges should show intolerance of racism. The Milwaukee Journal, p. 13J.

Simpson, Janice C. (1987, April 3). Black college students are viewed as victims of subtle racism. The Wall Street Journal, pp. 1, 23.

Sowell, Thomas (1989, February 13). The new racism on campus, Fortune, pp. 15-116, 118 and 120.

Stanford, Gregory D. (1987, May 10). Blacks say racism lurks beneath the calm at UW campuses. The Milwaukee Journal, p. 15A.

Steele, Shelby (1989, February). The recoloring of campus life. Harper's Magazine, pp. 47-55.

Stevens, William K. (1988a, April 11). In tense times at Penn, enter Farrakhan. The New York Times, p. 10 .

Stevens, William K. (1988b, April 15). Pennsylvania students exercise restraint on Farrakhan visit. The New York Times, p. 11.

Thomas, Gail E. (1981). Black Students in Higher Education: Conditions and Experiences in the 1970's. Westport, CT; Greenwood.

Tobin, James (1987, March 23). U-M students seek black leaders' help. The Detroit News, p. 1.

University of Michigan (1987). The attitude gap. Research News, Nov./Dec.: 15-17.

Wilkerson, Isabel (1988, April 17). Campus blacks feel racism's nuances. The New York Times, pp. $1,17$.

Williams, Dennis et al. (1987, February). Is the dream over? Newsweek, pp. 10-14.

Wilson, Reginald (1986, September 22). Letter to chair of UW Regents Education Committee regarding UW system, minority/disadvantaged program initiatives. Washington, DC: Office of Minority Concerns, American Council on Education.

Wilson, R. L., and Melendez, S. E. (1986). Minorities in Higher Education. Washington, DC: American Council on Education.

Yardley, Jonathan (1988, June 5). Sheltered ivory towers can't hide from racial bigotry plaguing society. The Milwaukee Journal, p. $11 \mathrm{~J}$. 